
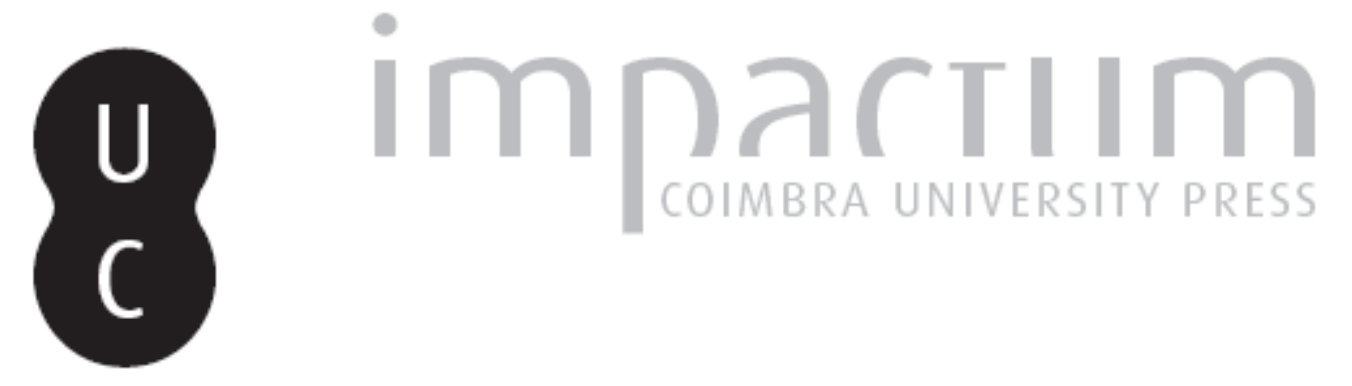

\title{
Plotino e Ireneu de Lyon contra os gnósticos: uma proposta para ela? Diferenças e paralelismos do contra-gnosticismo de Ireneu e de Plotino
}

Autor(es): $\quad$ Santos, David G.

Publicado por: Annablume Clássica

URL persistente:

URI:http://hdl.handle.net/10316.2/24482

DOI:

DOI:http://dx.doi.org/10.14195/1984-249X_5_10

Accessed : $\quad$ 26-Apr-2023 10:14:56

A navegação consulta e descarregamento dos títulos inseridos nas Bibliotecas Digitais UC Digitalis, UC Pombalina e UC Impactum, pressupõem a aceitação plena e sem reservas dos Termos e Condições de Uso destas Bibliotecas Digitais, disponíveis em https://digitalis.uc.pt/pt-pt/termos.

Conforme exposto nos referidos Termos e Condições de Uso, o descarregamento de títulos de acesso restrito requer uma licença válida de autorização devendo o utilizador aceder ao(s) documento(s) a partir de um endereço de IP da instituição detentora da supramencionada licença.

Ao utilizador é apenas permitido o descarregamento para uso pessoal, pelo que o emprego do(s) título(s) descarregado(s) para outro fim, designadamente comercial, carece de autorização do respetivo autor ou editor da obra.

Na medida em que todas as obras da UC Digitalis se encontram protegidas pelo Código do Direito de Autor e Direitos Conexos e demais legislação aplicável, toda a cópia, parcial ou total, deste documento, nos casos em que é legalmente admitida, deverá conter ou fazer-se acompanhar por este aviso.

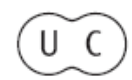



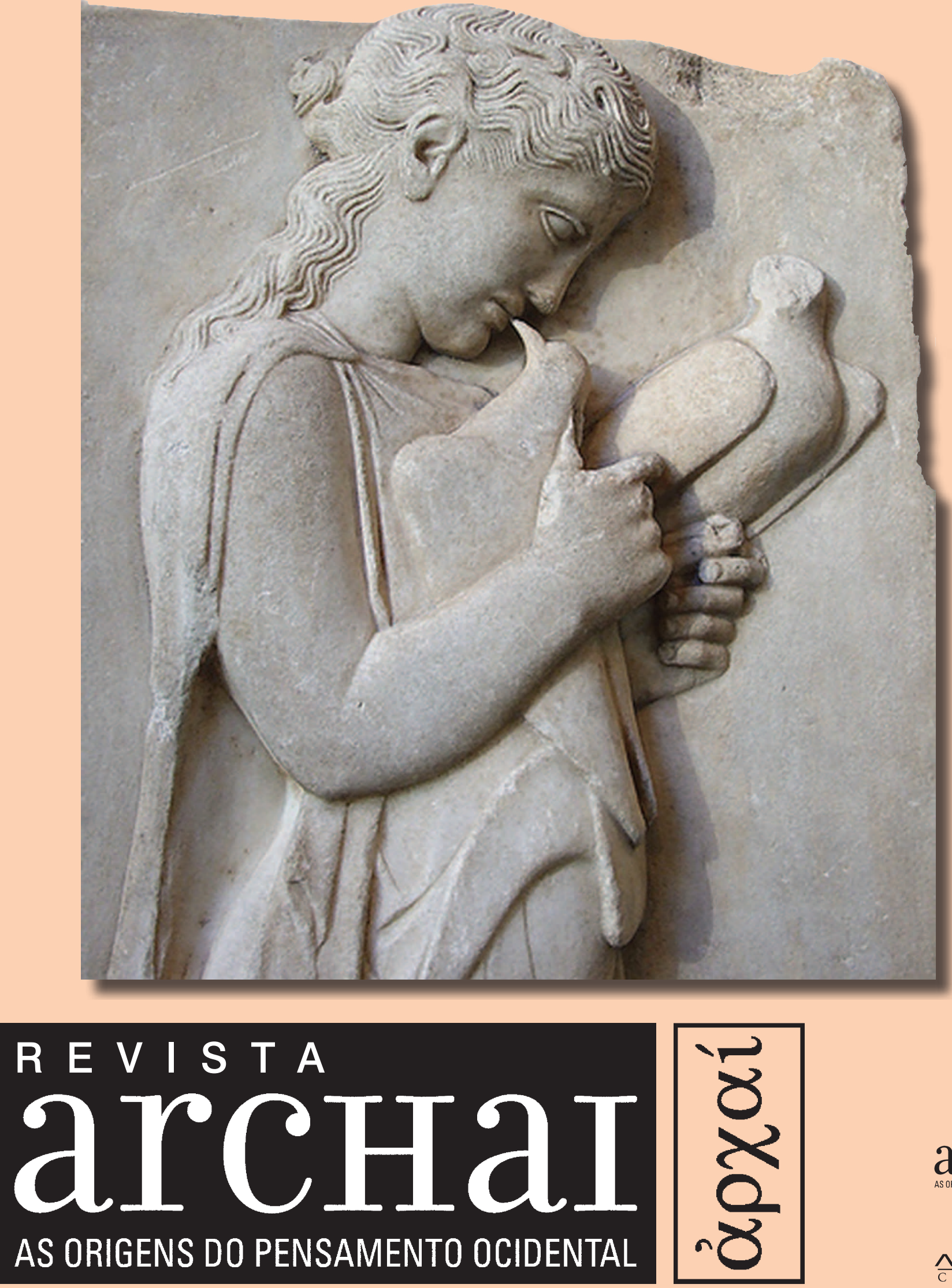


\section{PLOTINO E IRENEU DE LYON CONTRA OS GNÓSTICOS: UMA PROPOSTA PARALELA? DIFERENÇAS E PARALELISMOS DO CONTRA- GNOSTICISMO DE IRENEU E DE PLOTINO}

RESUMO: Neste artigo procuro argumentar que apesar de Plotino e Ireneu serem reconhecidos como autores com posições filosóficas semelhantes no que diz respeito ao Gnosticismo, não há verdadeiras razões para admitir aquele tipo relação especulativa entre ambos. Não há dúvida que Plotino e Ireneu de Lyon parecem ter concepções semelhantes quando criticam o movimento Gnóstico. É seguro afirmar que estudos recentes sobre Plotino e Ireneu sugerem que ambos contêm respostas parecidas às questões que o ambiente Gnóstico daquele tempo colocava. Neste artigo procuro demonstrar que apesar de existirem relações inquestionáveis entre os dois filósofos, a totalidade da anatomia geral e os objectivos dos seus trabalhos especulativos são tão conceptualmente diferentes e diversos que em rigor não se pode reconhecer nenhuma posição semelhante entre os dois. Procuro também sugerir que o tipo de aproximação que olha para Plotino e Ireneu, no que diz respeito ao Gnosticismo, como análogos deve-se basicamente a um problema de definição que o conceito de Gnosticismo normalmente implica em alguns estudos académicos. Neste artigo pretendo mostrar que tanto Plotino como Ireneu começam a especular num ambiente religioso muito semelhante com problemas filosóficos análogos para resolver mas os horizontes dos dois são muito diferentes porque em rigor ambos partem de fundamentos intelectuais muito diferentes.

PALAVRAS-CHAVE: Ireneu de Lyon, Plotino, Gnosticimo, Religião, Filosofia, Teologia.
1. Universidade da Beira Interior, Portugal.
David G. Santos ${ }^{1}$

‘...] it is amazing that almost all of the ideas that Plotinus finds objectionable in the Gnostics have been asserted by himself too in one form or another. The polemic against the Gnostics [...] turns out to reveal a vital tension in Plotinus's own system, rather than a mere external differentiation of his doctrines from others.'

Joseph Katz, 'Plotinus and the Gnostics', Journal of The History of Ideas, XV, 1954, p. 289-298.

\section{1. a) Introdução e enquadramento teórico.}

A presente reflexão debruça-se de uma maneira precisa sobre as decisões metodológicas e sobre o próprio âmbito temático que animam de forma fundamental este trabalho. Não tendo a pretensão de filogeneticamente cobrir os autores que nos propomos trabalhar, o que principalmente nos importa relevar à partida são justamente as dificuldades hermenêuticas que assaltam qualquer tentativa de uma compreensão exaustiva dos modos próprios da retórica argumentativa tanto do pensamento de Plotino como de Ireneu. Não faltariam sem dúvida eminentes estudiosos que apontassem para a grande dificuldade que subjaz à compreensão do pensamento de um ou outro autor: 
por surpreendente que seja, temos de ambos os lados dois pensadores que se aproximam dos seus problemas com uma abordagem que se esforça se não por um determinado sistematismo, pelo menos por uma certa partilha de compromissos intelectuais que decide os trâmites principais do pensamento dos dois autores. Duncker na sua obra Des heiligen Irenäus Christologie im Zusammenhange mit dessen theologischer und anthropologischer Grundlehre ${ }^{2}$ inclina-se no sentido de apontar no pensador cristão um pensamento sistemático: de João, Ireneu teria retirado uma teologia, de Paulo uma Antropologia, e uma Cristologia própria coroaria o sistema. Ziegler ${ }^{3}$, Harnack $^{4}$, Beuzart ${ }^{5}$ e Lawson adoptaram posições relativamente a estas questões bem mais cuidadosas: haveria em Ireneu uma doutrina eventualmente auto-comprometida com alguns pontos do seu pensamento ('many details of his [Irenaeus] thought have common effects ${ }^{6}$ ), mas em grande medida não seria possivel descortinar uma possibilidade de síntese no seu pensamento, sendo ao invés observável o modo como o bispo de Lyon concatena de forma sólida alguns dos cintilares e matizes da

ABSTRACT: In this paper, I argue that although Plotinus and Irenaeus are recognized as authors with similar philosophical positions concerning Gnosticism, there is no reason to acknowledge that kind of speculative relationship between them. Undoubtedly, both Plotinus and Irenaeus of Lyon seem to agree when they criticize the Gnostic movement. Even recent studies of Plotinus and Irenaeus suggest that they have very similar responses to the questions posed by intellectual Gnostics of their time. However, I try to demonstrate that though there is an unquestionable relationship between the two writers, the general anatomy and goals of their speculative work are so conceptually diverse that there is really no support for the position that the two authors are alike. I also suggest that the academics who say the approach of Plotinus and Irenaeus to Gnosticism is analogous have a definition problem. In this paper, I claim that both Plotinus and Irenaeus started contemplating a very similar religious ambiance with parallel philosophical problems to solve, but their horizons are different because they had such different intellectual foundations.

KEYWORDS: Ireneaus of Lyon, Plotinus, Gnosticism, Religion, Philosophy, Theology. tradição de que é filho. Plotino e Ireneu de Lyon, apesar de praticamente contemporâneos, pertencem a mundos intelec-tuais de raízes diferentes: Platão, Aristóteles, estóicos, pré-socráticos e todo um ambiente intelectual de um neopitagorismo na senda de um médio-platonismo herdeiro da tradição grega clássica são indubitavelmente as grandes referências das perspectivas plotinianas fundamentais. Os problemas do filósofo egípcio são muito diferentes daqueles sobre os quais o bispo de Lyon se debruça: apesar de sem dúvida se poder ler também a totalidade da obra de Plotino numa perspectiva unitarista e daí, portanto, retirar um sabor sistemático mais vivo ainda do que aquele que retiramos do texto de Ireneu, o mais flagrante são as diferenças relativamente ao conteúdo que pautam as interrogações e respostas dadas por ambos os pensadores. Nada é mais estranho, pelo menos de um ponto de vista superficial, a Plotino que as ideias de Encarnação, de Mediador, de Àgape, de Graça, de Redenção num «Deus escondido» conforme de resto na tradição judaico-cristã: a filosofia plotiniana é essencialmente um sistema de matiz mais ou menos heteróclito, 'perspec-tivista' e conduzido por uma lógica interna do desvelamento metafísico que não faz apelo a uma Revelação que implique uma Mensagem das Escrituras e uma Mensagem veiculada através de uma encarnação em direcção a uma escatologia total, redentora e da ordem da salvação. Apesar das diferenças de fundo que moderam o discurso entre estes autores, este trabalho enquadra-se justamente no estudo de um ponto de intersecção intelectual talvez surpreendente entre os dois autores: quer Plotino quer Santo Ireneu ergueram fundamentalmente dois grandes textos contra 'uma corrente' filosófica, mística e religiosa que aos olhos dos nossos autores parecia constituir uma novidade naquela época e que punha em perigo tanto a sobrevivência do cristianismo antigo, como da filosofia genuinamente herdada do mundo clássico grego. Historicamente não existe nenhum vínculo de contacto contemporâneo entre a filosofia plotiniana e o pensamento do bispo de Lyon, mas é hoje em dia um ponto assente de que no que diz pelo menos respeito ao tratamento da questão do gnosticismo, Plotino e Ireneu, dão duas respostas que se abeiram
2. Cf. Duncker, Des heiligen Irenäus Christologie im Zusammenhange mit dessen theologischer und anthropologischer Grundlehre, Göttingen, 1843. Embora mais antiga pode ser também consultada: Historiae doctrinae de ratione quae inter peccatum originale et actuale intercedit, pars continens Irenaei, Tertulliani, Augustini sententias, Göttingen, 1936 .

3. Cf. Ziegler, Irenäus der Bishof von Lyon, Berlin, 1871.

4. Cf. Pode e deve ser lido com muito proveito: 'Der PresbyterPrediger des Irenäus (IV, 27, I -32, I)' in Philotesia. Paul Kleinert zum 70. Geburstag, ediç̧ão de A. von Harnack et al., Berlin, 1907, pp. 1-37.

5. Cf. Beuzart, Essai sur la théologie d'Irénée, Le Puy, 1908.

6. Cf. Lawson, The Biblical theology of St Irenaeus, London, 1948, p. 22. 
7. N. B.: Pela importância que nos parece ter, dado o objectivo fundamental deste trabalho, vale a pena citar Eric 0sborn: 'When we come to Plotinus, however, we find someone who is profoundly useful for the study os Irenaeus. Historically there is no connection; but [...] philosophically, there is near identity in their response to Gnosticism.'; Cf. Eric Osborn, Irenaeus of Lyons, Cambridge, 2001, p. 44.

8. CF. M. A. Williams, Rethinking 'Gnosticism'. An Argument for dismantling a dubious category, Princeton, 1996. p. 264, (a trad. do inglês que citamos é nossa). Pese a cautela própria de que todas as avaliações histórico-filosóficas devem ter, este revivalismo e simpatia pelo gnosticismo parece-nos ser um legado profundamente moderno no sentido de que é um facto inegável de que $o$ interesse que começou a re-surgir foi concomitante com 0 estabelecimento do modernismo, da rejeição da tradição e da rejeição da autoridade. De uma certa forma, para os modernos, os heréticos deviam estar 'correctos'

na medida em que a tradição estava 'errada'; para o que aqu foi referido, é fundamental uma obra como a de Jefferey Stout: The Flight from authority Religion, morality and the quest for autonomy, Notre Dame, 1981,

pp.2-3. de uma 'identidade próxima' de conteúdos sobre as quais nos debruçaremos no corpo deste trabalho. ${ }^{7}$ Em 1980, R. A. Norris no Union Seminary Quarterly Review escreveu um ensaio precisamente sobre este improvável ponto de encontro destas duas figuras: 'Irenaeus and Plotinus answer the Gnostics': a note on the relation between Christian thought and Platonism' é um artigo que se demarca por uma perspectiva positiva relativamente ao encontro dos dois autores: ambos teriam argumentos semelhantes contra os Gnósticos - como a título de exemplo, a ideia de uma proliferação absurda de primeiros princípios e de um constante enegrecimento da realidade terrena e material. Esta breve meditação instala-se de um ponto de vista recapitulativo desta questão, mas não só: depois de uma obra tão desafiadora como a de M. A. Williams, Rethinking 'Gnosticism' - An argument for dismantling a dubious category, o panorama desta discussão alterou-se significativamente. Não se trata apenas de um problema de generalização grosseira ao falar-se do 'gnosticismo', mas de forma mais conspícua trata-se de questionar a existência da figura histórica tal qual, a título de exemplo, no contexto de Plotino e Ireneu, nos surgem os Gnósticos. Williams mostra como é possível argumentar através de uma rigorosa exegese dos textos Gnósticos, que não só as ideias destes não eram parasitárias de um legado religioso greco-judaico, mas que de igual modo não é possivel dizer dos seus autores que como um grupo fossem de alguma forma mais avessos ao corpo e ao mundo material que a generalidade da cultura da época. Como tem sido sugerido ao longo da história hermenêutica, os Gnósticos não eram ascéticos ou libertinos, nem deterministas, nem elitistas: os Gnósticos 'emergem como criaturas sociais [...] que a julgar pela forma como escrevem mais parece que muitas vezes tiveram mais a intenção de precisamente afrouxar a tensão sócio-cultural entre o seu mundo religioso e o mundo social mais alargado' ${ }^{8}$. Neste sentido esta reflexão instala-se sobretudo no campo de uma discussão sobre a realidade dos textos que nos levam, regra geral, a afirmar a tese de que Ireneu e Plotino tentaram a seu modo - com os conteúdos e formas de argumentação retórica que então sabiam - defender respectivamente um cristianismo e o um classicismo à maneira do mestre Platão. b) Sumário de Missão.

No seguimento do que já foi previamente adiantado, este trabalho tem como principais pontos de apoio dois textos fundamentais a este respeito de Plotino e Ireneu. 0 tratado n. ${ }^{\circ}$ 9, ПРО ГNO $\Sigma T I K O \Sigma$, da II Enéada de Plotino, bem como o famoso Adversus Haereses de Ireneu são os pontos de partida desta breve meditação. Tendo sempre em conta a forma e o conteúdo dos textos, analisando alguns passos fundamentais das referidas obras, tentaremos responder às questões de trabalho que aqui se colocam com premência: quando Ireneu e Plotino se movem contra os heréticos, que significam para ambos os autores as heresias que procuram combater? Com que argumentos, decisões e fundamentos empreendem as investidas de ataques que perfazem? Existem algumas semelhanças relativamente às respostas de ambos os autores? A confirmar-se a identidade próxima entre os principais argumentos dos autores contra as heresias gnósticas, será que as motivações de causa que os impelem para tais respostas, podem ter um fundo comum passível de ser esclarecido?

Como conclusão esperamos conseguir argumentar com sucesso no sentido de afirmar apenas uma semelhança aparente entre os dois autores no que diz respeito ao tratamento desta questão. Plotino e Ireneu só aparentemente dão respostas semelhantes; só na superfície de algumas linhas de força da reflexão plotiniana se pode aproximar o pensamento do bispo de Lyon. Diferentemente de E. Osborn e de R. A. Norris, cremos que em rigor não se justifica uma aproximação entre o filósofo e o bispo tal como foi por eles desenhada: Plotino e Ireneu, a terem algumas semelhanças, estas apenas pertencem a um conjunto de características de todo um Zeitgeist, o que, em nosso entender, não justifica a quase identidade referida por alguns estudiosos entre os dois autores antigos.

\section{Adversus Haereses: formas, figuras e conteúdo da argumentação de Ireneu}

Em Ireneu de Lyon, emerge muito cedo na sua obra, Adversus Haereses, a ideia de um Deus 
infinito: imediato numa unidade universal a regra da sua presença e da sua criação está na sua bondade e beleza sem termo. Enquanto transcendente é de igual forma imediato e presente através do seu amor: o Deus desconhecido tornou-se conhecido como Intelecto universal através da sua economia na criação. Deus é último, pessoal, transcendente e causa de todas as coisas: Deus é Uno mesmo que os heréticos assim não o creiam (1.22.1) e à sua grandeza nada falta (4.19.3). Incriado e nãonascido, Deus é sem princípio e sem fim (2.34.2; 3.8.3;4.38.1) - é a perfeição (4.38.3), a eternidade e a imutabilidade $(2.34 .2 ; 4.11 .2 ; 4.38 .1)$. Deus é sustento de todas as coisas sem ser por nada sustentado (2.30.9): a sua imanência coincide com a sua transcendência porque Deus, na sua bondade infinita, é o criador de todas as coisas (4.41.1) e por isso todas se conformam com a sua providência e são governadas na sua economia (4.36.6). Altissimus, omnipotens, super omnia Deus (2.6.1-3): o Deus de Ireneu não pode nunca ser um escravo da necessidade (conforme um Zeus de Homero; 5.4.2; 2.5.4) Todas as coisas estão sujeitas à sua vontade: 'não movido por outra coisa, livremente através da sua decisão, ele criou todas as coisas, pois só Ele é Deus, o único Deus, o único criador, o único pai, o que contém todas as coisas e o que dá existência a todas as coisas' (2.1.1). Amor, poder e sabedoria sem limite - tudo são aspectos de uma opulência de Deus que corresponde em simultâneo à sua simplicidade absoluta (2.13.3; 2.28.4;4.11.2). Deus é todo Intelecto, todo Palavra, todo Espírito, todo Luz e sempre idêntico a si mesmo ${ }^{9}$ (3.3.3), todo substância (hypostasis), Ele é a fonte de todas as coisas (1.6.3). 0 ataque que Ireneu desencadeia contra os Gnósticos prende-se justamente um pouco com estas questões: o bispo de Lyon ataca os Gnósticos pela sua falta de consistência argumentativa. 0 Deus uno todo-poderoso e todo criador dava a Ireneu um princípio racional: é simplesmente espantoso o facto de que muito do que Ireneu refere acerca de Deus e dos Gnósticos se dever tanto ao mundo grego do qual Plotino também é filho. Os pontos de semelhança parecem evidentes desde logo numa tendência basilar para um estoicismo modificado e mitigado nalguns pontos: tal como em Ireneu, a teologia estóica gravita em torno da construção de um Intelecto cósmico que assiste e subsiste em toda a sua criação. Deus 'trabalha' quer de 'cima', quer a partir de 'dentro' dos seres - o contraste com o estoicismo está justamente aqui: o criador estóico é de tal forma imanente ao mundo que se identifica com ele; no cristianismo de Santo Ireneu, Deus é sem dúvida simultaneamente transcendente e imanente, é simultaneamente indivisível, homogéneo, inteiro e idêntico em todas as coisas, mas é também, por contraste, o que pervaga todos os entes conforme uma economia que the é própria na sua simplicidade não composta e através da qual se harmoniza o bem e o mal numa genuína relação de interdependência. A perfeição divina do criador de Ireneu demarca-se pela sua dupla face de um divino que é em paralelo absolutamente transcendente, mas ao mesmo tempo absolutamente contingente. Contra os dualistas da criação, Ireneu reclama uma Cristologia refinada da ordem da recapitulação e da economia: a perfeição de Deus consuma-se na sua capacidade de consumação no contingente, numa transcendência que se aproxima do mundo através do seu amor infinito. 'Totus exisistens mens, totus exsistens logos' (2.88.5), Deus está desde logo anunciado pelos justos e profetas do passado: a luta de Ireneu contra os Gnósticos demarca-se à partida desde o início da forma e do conteúdo da luta plotiniana contra as heresias: Ireneu, pela primeira vez na história da teologia, vai ao texto evangélico, fundamentando-se e referindo-se ao texto sagrado como a única autoridade verdadeira; enquanto Plotino, ao bom modo da tradição de que é herdeiro, vai reconduzindo o seu pensamento à verdadeira interpretação de Platão.

Entre o Adversus Haereses e o ПРО

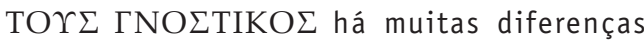
tanto na forma como no próprio conteúdo das objecções e das contra-construções teóricas que são feitas ao longo dos textos. Ireneu opta de forma consciente por uma verdadeira exposição e contraargumentação das doutrinas mais importantes do gnosticismo: atacando os diversos movimentos filosófico-religiosos da falsa gnose, expõe no livro I e de forma absolutamente pormenorizada o que professavam. Manipulando com destreza as ideias
9. Não sendo o propósito principal deste trabalho demonstrar 0 que filogeneticamente subjaz ao pensamento de Ireneu ou Plotino, fique desde já a ideia de que ambos são herdeiros de uma tradição grega em último reduto passivel de ser reconduzida ao famoso fragmento de Xénofanes (G. S. Kirk, J. E. Raven and M. Schofield, The Presocratic philosophers, Cambridge, 1983, pp. 166-72) e aos seus múltiplos usos e interpretações ao longo da história da filosofia e da religião. Para Dodds bem como Krämer todas as ideias que gravitam em torno da questão do Uno e do Intelecto são passíveis de serem devidamente reconhecidos no famoso Parménides de Platão. A partir dos anos 80, com o artigo de Doods ' The Parmenides of Plato and the origin of the Neoplatonic One' esta recondução passou a ser um lugar comum. Apesar de Ireneu, à semelhança por exemplo de Tertuliano, manter quase sempre uma atitude bastante negativa sobre os filósofos

$(2.14 .3 ; 4)$, não deixa de fazer uso dos instrumentos da filosofia para proveito do sólido estabelecimento do seu pensamento. Para ver um pequeno comentário sobre a referida influência em Ireneu, vide: Eric Osborn, Irenaeus of Lyons, Cambridge, 2005, pp. 32-38; Robert Grant, Irenaeus of Lyons, New York, 1997, pp. 44-45; 193. Ireneu aceita de forma explícita alguns dos mais fundamentais valores nitidamente herdados da cultura clássica e que paradoxalmente vão ser também no interior da obra do bispo de Lyon impulsionadores do seu pensamento: 0 amor socrático à verdade e o valor de beleza $\mathrm{e}$ ordem, são aspectos constitutivos da sua reflexão. A ideia de Meijering de que o 'dogma' de Ireneu é concebido e construído por uma mentalidade grega sobre uma 'fundamentação evangélica' é aqui um aspecto importante a ter definitivamente em conta. Cf. 'Some observations on Irenaeus polemic against the Gnostics', God, being history: studies in patristic philosophy, 0xford and New York, 1975, pp. 31-38. Voltaremos ao longo deste trabalho, evidentemente, à problemática da influência grega no pensamento de Ireneu. 
às quais se opunha, o seu movimento ao longo de todo o livro é sempre o de uma exposição clara e posteriormente o de um rebatimento lógico das teses à guarda da autoridade bíblica. Ireneu é perito em relacionar, em reconduzir a seu modo as doutrinas dos Gnósticos aos seus supostos ancestrais: desde Homero, comedió-grafos e tragediógrafos, a alguns pré-socráticos como Demócrito e Epicuro, o bispo de Lyon pretende apresentar ao leitor a forma como os heréticos introduzem e modificam ideias em noções que já eram em si próprias vazias de piedade e de religiosidade. Vale a pena citar, o texto pela própria mão de Ireneu:

' Um poeta da Antiga Comédia, Aristófanes, falou com muito mais probabilidade e elegância sobre a génese de tudo numa teogonia. De acordo com ele, da Noite e do Silêncio foi emitido o Caos, do Caos e da Noite, o Amor; do Amor apareceu a Luz, e depois toda a primeira geração dos deuses. [...] A partir daqui os valentinianos moldaram o seu mito como uma história natural, simplesmente mudando os nomes dos deuses e mostrando o mesmo princípio e a emissão de todas as coisas. [...] Na verdade eles transferem para o seu próprio sistema tudo o que já foi dito nos teatros em todo o lugar por actores de vozes esplêndidas, ou então usam o mesmo enredo e simplesmente mudam os nomes. [...] A doutrina que eles apresentam é nova porque foi elaborada recentemente com uma arte nova, mas na verdade é velha e sem valor, porque foi costurada junta a partir de doutrinas antigas que cheiram a ignorância e à falta de religião.' ${ }^{10}$

\section{Adversus Haereses, 1.14.1-2.}

0 ataque de Ireneu é formalmente ordenado 12. Sobre este conceito existe uma obra monumental que pode ser consultada com proveito: Alain Le Boulluec, La notion d'hérésie dans la littérature grecque IerIIIeme siècles, 2 vols, Paris, 1985.

13. Sobre este modelo vide: $D$.

T. Runia, 'Philo of Alexandria and the Greek haeresis-model'; Vigiliae Christianae, 53, 1999 pp. 117-47. Sobre o que referimos veja-se ainda: A. Benoit, 'Irénée

et l'hérésie, les conceptions hérésiologiques de l'évêque de Lyon', Augustinianum, 20, 1980

pp. 59-91.
Lyon escreve no Adversus Haereses principalmente contra os Valentinianos mas fez uso também de outras heresias gnósticas para indicar a sua verdadeira raiz: à luz do verdadeiro cristianismo, todos os movimentos gnósticos estão não só errados do ponto de vista lógico-argumentativo como não se pode neles reconhecer uma verdadeira sucessão apostólica directa. 'A aproximação básica de Ireneu ao gnosticismo é genética' - refere Robert Grant ${ }^{11}$, ou seja: partindo do fundamento de que existe uma unidade entre a verdade e a Santa Escritura, os movimentos gnósticos surgem para Ireneu como aqueles que vivem no constante fervilhar do desmembramento da coerência e da verdade. A fonte da verdade é Sagrada Escritura e a traditio ab apostolis: estes dois eixos são o último reduto da validada por uma regra de fé que apenas se apresenta num tríptico com o Pai, o Filho e o Espírito Santo. Ireneu usa poucas vezes a palavra 'heresia' ${ }^{12}$ ao longo do próprio Adversus Haereses - e tal aspecto parece-nos substantivo no que diz respeito à técnica argumentativa: em substituição de 'haerisis', Ireneu usa o termo 'omnis' em mais de metade dos exemplos descritivos e exaustivos que faz das doutrinas em causa. 0 Adversus Haereses está construído à imagem da técnica oratória dos gregos e mais especificamente de Filón ${ }^{13}$ : por causa da força do argumento, o bispo pretende apresentar uma súmula das heresias e por isso prefere quase sempre não designar um outro herege em particular, mas sim 'os heréticos', numa pluralidade transversal. Para Ireneu, os heréticos emergem das antípodas da tradição cristã: imbuídos num clima de mistério e de secretismo, surgem por contraste com a unidade da Fé, com uma multiplicação de elementos e de especulações teóricas em torno do princípio e das realidades que dele advêm. Se os Gnósticos multiplicam de forma escandalosa o número de princípios fundamentais do mundo e se referem ao deus criador como um deus 'fruto da falta e da carência', Ireneu não podia senão questionar-se:

'Como pode haver acima deste Deus um outro Pleroma, ou Princípio ou Poder ou outro Deus, quando é necessário que o Deus de todos estes contenha tudo na sua imensidade e seja por nada contido? Se houvesse 
alguma coisa fora dele, ele já não seria o Pleroma de tudo, nem ele conteria tudo; pois para este Pleroma ou Deus acima de tudo existiria a carência do que se encontra fora dele.'

Adversus Haereses, 2.1.2.

Ireneu insiste: é preciso desmascarar (detectio) e retirar (eversio) de cena o sectarismo perigoso dos movimentos gnósticos $(1.31 .3,4)$ e a sua qualidade 'camaleónica' de poder assimilar em si filosofias e tendências politeístas que se infiltravam na comunidade cristã de tal forma que quer críticos judeus quer críticos pagãos não os distinguiam entre si. Esta fluidez do gnosticismo pode ser explicada talvez por uma forte tendência estética que parecia animar o debate religioso e filosófico mais popular da época ${ }^{14}$ : com um adversário de tal forma proteu, o discurso de Ireneu parece corresponder sem dúvida a um outro milagre da mentalidade grega. Ireneu faz também uso de imagens, do mundo estético-metafórico em que vivia, mas fá-lo com um intuito preciso: o seu esquema de ataque multiplica-se exaustivamente ao longo de todo o Adversus Haereses, entre a abundante exposição dos seus oponentes, 0 rebatimento lógico dessas ideias e o regresso à tradição $(3.3 .1 ; 3.4 .1 ; 3.4 .2)$. 0 bispo contrasta a universalidade do saber cristão com a ganância dos mestres Gnósticos (2.31.3;2.32.4): a simplicidade da fé cristã e da unidade da Igreja é justamente perpendicular ao saber heterogéneo e pretensioso dos Gnósticos ${ }^{15}$ e dos que se iludem seguindo-os. Esta unidade da Igreja cristã, Ireneu exprime-a na ideia de que o Deus de Abrãao, o Deus de Isac, de Jacob e de Israel é o mesmo Deus, Pai de Jesus Cristo, o criador de todas as coisas e acima do qual não há outro (vide a famosa oração do bispo de Lyon em 3.6.4). A resposta positiva de Ireneu aos problemas levantados por esta histeria do mundo gnóstico e do seu fervilhar tão próprio é todo um encadeamento coerente de quatro conceitos fundamentais que concorrem para a constituição de uma soteriologia salvífica - intelecto, economia, recapitulação e participação são justamente as noções que parecem nortear de forma subjacente muitas das respostas do bispo:
Intelecto: Deus é o Intelecto Universal, a fonte criadora de todas as coisas, o omnipotente, omnipresente e omnisciente.

Economia: através da actividade de Deus, o seu plano pode ser distinguido; o movimento e a mudança da actividade divina na história do natural fazem parte do Intelecto divino. A história é o resultado de um conjunto de divinas economias comprometidas com uma coerência, com uma lógica de sentido de toda uma economia geral inclusiva.

Recapitulação: a mudança é um sinal da actividade divina - toda a história encontra o seu significado na pessoa de Jesus que é o princípio da Verdade, do Bem e do Ser. Jesus Cristo é a justaposição necessária do princípio com o fim, do significado da história consumado.

Participação: dos outros três conceitos, emerge o corolário - o fim de todas as coisas é a participação de Deus no Homem e de Homem em Deus.

0 centro da diatribe de Ireneu com os Gnósticos é essencialmente uma interpretação lógica e estética das escrituras, é uma luta entre a lógica do raciocínio e certamente uma luta de metáforas e de figuras de estilo. Decet - fieri potest - ergo est, convém, é possível, logo é : este é o núcleo da lógica de exposição de Ireneu, que à semelhança de um filósofo, está interessado em argumentar a partir de uma exposição do que considera um erro. 'Deus cria, o homem é criado' (4.11.2), mas nisto não se pode esquecer de que há uma essencial participação do divino em toda a criatura; daí que para o Bispo de Lyon, a verdadeira gnose só pode ser apreendida nos ensinamentos dos apóstolos e da 'instituição antiga da igreja' (4.33.8) 'que está por todo o lado [no mundo] por causa do seu amor por Deus' (4.33.9). Ireneu é sem dúvida um mestre da retórica e daí que o seu humanismo optimista e dinâmico o leve a relevar os aspectos que considerava negativos nos movimentos gnósticos:

a) o dualismo cósmico de um mundo corrompido e determinado também pelo defeito, pela carência e pela corrupção da matéria.

b) um Deus absolutamente transcendente e nunca doado por um amor verdadeiro à proximidade no mundo.
14. Reproduzimos uma ideia de H. U. Balthasar, Herrlichkeit - Eine theologische Ästhetik, vol II, Eisiedeln, 1962, p. 38-40.

15. N. B.: Ireneu chega a relevar a falta de uma sucessão verdadeira da tradição nos Gnósticos: 'Antes de Valentino não havia discípulos de Valentino, antes de Marcião não havia discípulos de Marcião; e nenhum dos outros enumerados acima como detentores de doutrinas existiam antes dos mistagogos e dos que descobriram a sua perversidade'. (a trad. é nossa.) Seguimos: Irenaeus, Against heresies, text, W. Harvey, 2 vols., Cambridge, 1857, 4.4.3. 
16. Os termos não são nossos; Cf. G. Vincent, 'Le corps de l'hérétique (la critique de la gnose par Irénée)', in Revue d'histoire et de philosophie religieuses, 69, 1989 p. 411

17. A ideia aparece também em Tertuliano. Vide por ex apologeticum 17.5-6; adversus Valentinianos 3.2. Seguimos texto de Justino pelo texto estabelecido em : Apologies, transl. by A. W. F. Blunt, Cambridge, 1911; The dialogue with Tripho, trans. A. Lukyn Williams, London, 1930

18. N. B.: Convém ter em conta pelo menos dois aspectos no que diz respeito à apreciação do texto plotininano: o primeiro é que os títulos que constam nos tratados das edições modernas das Enéadas não são da autoria do filósofo egípcio mas do seu discípulo, Porfírio; de igual forma, o segundo aspecto a ter em conta é que também os tratados que perfazem as Enéadas na configuração que conhecemos hoje em dia é um produto da compilação feita pelo mesmo discípulo. Daí que neste caso concreto, o tratado n. ${ }^{\circ} 9$ para os especialistas contemporâneos se encadeia com o tratado $n .^{\circ} 5$ da V Enéada. Basta esta observação para reconhecer como qualque avaliação da obra de Plotino, ou de qualquer parte dela, po superficial que seja, é uma tarefa por si só complexa e difícil.

19. N. B.: Sobre esta 'generalidade' com que Plotino trata a questão do gnosticismo deve ser tomado em linha de conta o facto de que Plotino no presente tratado, em II.9.10 refere que tem 'alguns amigo' entre os Gnósticos e daí que tenha que ter algum cuidado na forma como lida com a questão.

20. Cf. J. H. Sleeman, Gilbert Pollet, Lexicon Plotinianum, Leiden, 1980 c) uma antropologia-teológica elitista no sentido de que só alguns humanos - nomeada-mente os que guardam em si uma centelha divina - são naturalmente afins a Deus e têm em si as sementes divinas que determinam, pela sua maior ou menor presença, as escolhas morais de cada indivíduo.

d) a existência do mundo e do humano, a sua liberdade e os seus desejos são explicados por uma queda pré-cósmica; a distinção clara entre 0 Deus criador - associado à imperfeição e ao Deus do Antigo Testamento - e um Deus desconhecido superior.

e) a ideia de que os indivíduos são libertados através do conhecimento da sua verdadeira natureza e da sua origem divina.

0 essencial, a súmula dos argumentos aduzidos por Ireneu ao longo da sua obra aglutinam-se sempre nesta sua ideia fundamental: é uma impossibilidade lógica que haja um princípio superior a Deus, o criador, e é uma necessidade - mais importante agora - que a sua criação seja fundamentalmente boa; o apelo dos Gnósticos à imperfeição do mundo e do Homem é fundamentalmente um sintoma da desconsideração do facto de que todas as criaturas estão inseridas numa economia participativa e recapitulativa do Intelecto Universal. Ao pessimismo histérico gnóstico - um pessimismo que concatena com dificuldade a ideia monstruosa do super-humano espiritual e do inumano material ${ }^{16}-$, Ireneu aponta um genuíno abandono da regra da verdade (2.27.1): o gnosticismo é por isso uma irracionalidade dogmática que não tem em conta a ideia de que Deus triunfa através das suas obras (3.10.2). 0 optimismo do bispo de Lyon pretende fundar-se numa legitimidade do pensamento, da escritura e da tradição. Daí que, a título de exemplo, Ireneu deva a Justino a ideia mais fundamental da sua obra: a de um optimismo teocêntrico ${ }^{17}$. Uma vez que um dos temas favoritos de Justino é precisamente a bondade divina, Ireneu avança com um Deus, o maximamente bom, que criou o mundo para o Homem (I apol. 10.2), de um Deus que ama todo o Homen com justiça e bondade (dial. 23.2), de um Deus que é imanente por amor a toda a sua criação, em suma, de um Deus que se torna também filho e cuja morte recapitula, recupera e junta em comunidade o que estava então afastado numa renovada participação de Deus na criação e por sua vez, da criação em Deus.

Já o relevámos várias vezes ao longo deste trabalho: Ireneu, apesar do seu manifesto registo cristão e da sua luta por um cristianismo supostamente expurgado do mundo gentio, não deixa de, ao mesmo tempo, mostrar múltiplas influências no seu pensamento. A começar no próprio movimento de fundamentação nalguns movimentos de pura retórica que já destacámos, passando por conceitos fundamentais como o de 'participação' ou de 'Intelecto', até ao simples facto de que é através do gnosticismo e da sua teosofia que se estimula a produção intelectual de Ireneu - o mais importante a ter em conta é todo este ambiente, este paradigma ou molde de herança grega e mais especificamente platónica. Ireneu vivia num mundo 'platónico' Intelecto, recapitulação, economia e participação são conceitos de toda uma nebulosa platónica da época do bispo de Lyon; mas apesar disto será que ainda assim se pode dizer com segurança que Ireneu e Plotino entreteceram argumentos aproximados? $\mathrm{Ou}$ será que crenças diferentes se podem exprimir em categorias iguais? E quão iguais são as categorias de Ireneu e de Plotino?

\section{Plotino contra os Gnósticos: formas, figuras e conteúdo da argumentação plotiniana.}

Todo o tratamento dado por Plotino no seu famoso tratado n. ${ }^{0} 9^{18}$ da II Enéada é muito diferente do trabalho que Ireneu desenvolve. A começar pela forma do tratamento, Plotino é bastante mais generalista ${ }^{19}$ ao longo de todo o seu texto, isto é, não obedece de maneira alguma ao esquema formal que Ireneu estabelece de exposição, argumentação e recondução à tradição para um rebatimento final. Para uma correcta avaliação do que se lê neste tratado do filósofo egípcio, importa reter que não é por mero acaso que no Lexicon Plotianianum ${ }^{20}$ não se regista uma única vez ao longo de toda a sua obra qualquer termo relativo aos 'Gnósticos'. Mencionados como ' $\alpha$ voĩ $\varsigma^{\prime}$ quem serão aqueles a quem Plotino se refere? E porquê a ausência de uma terminologia 
directa? 0 tratado de Plotino é longo e intrincado; tão ou mais complexo como o texto de Ireneu no Adversus Haereses - e todavia uma coisa é certa: como aliás é característico do texto plotiniano ${ }^{21}$, o filósofo não parece estar de forma primordial realmente preocupado em rebater fundamentalmente tal ou tal inimigo especulativo, mas ao invés, Plotino parece apostar numa explicitação das suas ideias fundamentais combatendo paralelamente outras teorias metafísicas. Desde logo, no primeiro parágrafo do II. 9, torna-se bem claro o que referimos: a primeira preocupação de Plotino é essencialmente metafísica e prende-se em torno da explicitação do que se pode entender pelo Bem. 0 Bem, o Uno, a natureza simples, é o primordial - o mais simples, o auto-suficiente que não é composto por partes, nem é por nada contido: o eterno ponto de partida e de chegada de Plotino é desde o princípio do tratado o móbil principal do próprio texto. 0 Uno aparece como o fundador positivo e ao mesmo tempo negativo do Ser: ele é o princípio explicativo e causal de todas as coisas na exacta medida de que tudo só pode ser compreendido com rigor se todas as coisas forem colocadas numa perspectiva unitária, numa lógica de um todo. São claras desde logo as intenções de Plotino no presente tratado: mais do que um tratamento crítico das teorias especulativas dos Gnósticos, Plotino escreve para dilucidar o seu trabalho intelectual sonegando sem pudor pormenores das teorias que lhe são contrárias. Neste tratado de Plotino - bem como, aliás, em toda a sua obra - não encontramos um delineamento exaustivo ou sequer rigoroso e fiel de qualquer fonte que o filósofo egípcio use ou combata: ao invés, Plotino vai amiúde oferecendo algumas pistas sobre os aspectos que the interessa denegrir nos seus opositores e aproveitando os momentos para expor de forma justaposta o seu trabalho.

0 Uno é a fonte espontânea, necessária, não-recíproca e naturalmente auto-difusiva ${ }^{22}$ de todos os entes (V.1.6.37-45; VI.7.8.17-22; III.8.837-38; V.4.1.1-13; V.3.15.7-11): A multiplicação desnecessária de princípios e fundamentos, de mediadores, de potências (II.9.1.21-28) e de entes são o ponto principal da celeuma:
'Se, então, não existe a partir de outra coisa, [se] não está noutra coisa [se não nele próprio e por ele mesmo] nem existe como uma composição [de vários princípios], então é necessário que nada lhe seja superior ( $\alpha \dot{v} \alpha \dot{\gamma} \gamma \uparrow$

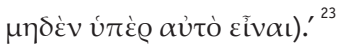

II.9.1.12-14.

0 argumento usado aqui - já atrás o tínhamos referido - é também utilizado por Ireneu: se Deus é o princípio superior, é simplesmente absurdo multiplicar fundamentos numa fantas-magoria de princípios ou, ao invés, reduzi-los, quer tomando o Intelecto como igual ao Uno, quer tomando a Alma como igual ao próprio Intelecto. Plotino estabelece - sem precisar sequer de um contraste vincado - com todo o vigor, a sua própria abordagem metafísica:

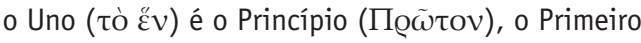
Bem; segue-se a primeira emanação do fundamento último da realidade, o Intelecto (voũs); e por fim, a Alma ( $\psi v \chi \eta ́)$. Estando o Uno acima do que é e do que pode ser pensado, o Intelecto 'é o que é sempre'

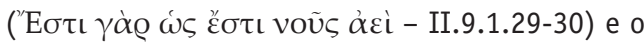
movimento, a introduzir-se, existe justamente na Alma e num princípio inteligível que procede do Intelecto e que torna este mediador entre a unidade da inteligência e a multiplicidade do mundo. Ao Intelecto, no entanto, não cabe um pensamento de si quedado na duplicidade da relação sujeito/objecto - Plotino aqui é absolutamente intransigente ao longo de todo o seu texto: a simplicidade do Uno é paralela à actividade estática do Intelecto e da impossibilidade lógica de se poder supor uma dualidade instalada no seio destes princípios A Alma é a entidade mediadora entre o princípio Inteligível e a multiplicidade: ela é uma natureza dentro de muitos poderes, parte dela está simultaneamente dirigida para as realidades inteligíveis, outra para as coisas da natureza e uma última parte está justamente no meio destas duas efectividades. 0 discurso de Plotino é complexo, entretecido e árduo: não se encaixa facilmente na ordem de discursos que habitualmente se vê nos textos característicos dos movimentos gnósticos. Ao contrário das mitologias personificadas dos Gnósticos, Plotino trabalha directamente sobre toda uma constelação de conceitos: para o filósofo egípcio - e conforme aliás
21. N. B.: Uma observação de Atkinson na esteira da apreciação que Hegel faz de Plotino nas suas Lições de História da Filosofia - Leçons sur l'histoire de la philosophie, trad. Garmiron, Paris, 1975, p.858.) explícita bem o que referimos: cada tratado de Plotino mais parece funcionar como uma exposição sempre do mesmo sistema. Leia-se: 'It is not too misleading to say that each treatise takes for granted the whole of his philosophy.'; Cf. M. J. Atkinson, Plotinus Ennead V. 1, A commentary and translation., 0xford, 1963, p. 10. Por não ser aqui o lugar indicado desvinculamo-nos evidentemente do trauma cronológico e de toda a problemática da avaliação diacrónica ou sincrónica da obra plotiniana, no entanto não podíamos deixar de assinalar a ideia de que há sem sombra de dúvida um pano de fundo filosófico permanente a toda a obra de Plotino.

22. E. R. Doods, 'Tradition and Personal Achievement in the Philosophy of Plotinus', in The Ancient Concept of Progress, Oxford, 1973, p.131.

23. N. B.: A tradução para português é nossa. Observando a tradução clássica de Armstrong da obra de Plotino mas quando pertinente introduzimos algumas alterações. Cf. A. H., Armstrong, Plotinus, Text with English translation by A. H. Armstrong, 7 vols., Cambridge Mass., 19661988. 
24. Cf. Ibidem.

25. N. B.: Apesar de algumas diferenças, existem consonâncias incontestáveis entre o

enquadramento dos Gnósticos dado pelo Adversus Haereses de Ireneu e o que se depreende da literatura de Nag Hammadi; o que importa reter é que geralmente a especulação mitológica

presente neste movimento é tendencialmente heteróclita regra geral confusa. De igual modo, e no seguimento desta heterogeneidade fundamental, também ao longo deste trabalho relevámos já as dificuldades que perfazem um estudo sistemático de Plotino (Bréhier chega mesmo referir uma 'contradição inegáve na teoria da emanação plotinana'; Cf. Emile Brehier, The Philosophy of Plotinus, Chicago, 1971, p.72).

Não é aqui certamente o local indicado para o explorar, mas não podíamos deixar de relevar que a título de exemplo um eminente estudioso dos temas Gnósticos e do mundo antigo como Hans

Jonas, vê nalgumas passagens de Plotino sobretudo uma especulação metafísica e filosófica de influência essencialmente gnóstica. Já tivemos oportunidade

de nos debruçarmos sobre o assunto num artigo: «Mitologia drama na Metafísica de Plotinow,

in CADMO - Revista de História

Antiga, Centro de História da Universidade de Lisboa, 18, 2008 (no prelo). 0 ponto fundamental desta questão é demasiado complexo para poder ser por nós aqui tratado, mas em suma, não nos parece que se possa reconduzir com verdade as problemáticas que animam o pensamento plotiniano às questões gnosticistas que fervilhavam naquele tempo. Se por um lado é sem sombra de dúvida verdade que as questões são semelhantes, por outro lado

não só as respostas diferem em grau de complexidade como diferem radicalmente no modo essencial de serem tratadas.

É certo que os problemas de Plotino partilham o mesmo clima intelectual de muitos textos gnósticos, mas importa relevar que as questões gnósticas são regra geral trabalhadas e resolvidas, fazendo recurso a uma mitologia especulativa sincrética de vária ordem, enquanto o filósofo egípcio recorre essencialmente a um trabalho metafísico complexo com um devido enquadramento se não platónico, pelo menos de legado clássico. Vale a pena no o conceito de «progresso» comum ao pensamento antigo - 0 anterior determina o posterior ${ }^{24}$ numa lógica interna de uma actividade causal que brota primordialmente de uma simplicidade espontânea. As figuras individua-lizadas, as múltiplas e diversas entidades mitíco-metafísicas postuladas pelos textos Gnósticos tal qual se podem ler amiúde a título de exemplo tanto na exposição que é feita tanto no Adversus Haereses, como nos famosos textos de Nag Hammadi $^{25}$ estão de facto muito longe deste tipo de discurso: do Uno tudo procede por emanação ( $\pi$ ○ódos); simultânea e exactamente, tudo regressa, tudo ascende ( $\varepsilon \pi \iota \sigma \tau \varrho \circ \emptyset \eta ́)$ de novo à origem do todo. A necessidade obriga à liberdade da doação de si mesmo para o outro: de uma variedade de bens Plotino induz um Bem supremo (I.7.1) que no seu poder infinito transcende tudo o que existe e é aquilo ao qual tudo aspira numa verdadeira teia de dependência total entre os seres e os princípios. 0 problema do mal não tem que ver com uma abordagem tal qual o faziam os Gnósticos na altura - Plotino sublinha-o bem: tal qual o vir-a-ser dos entes à luz do mundo não se pode colocar num certo e determinado momento do Tempo, de igual modo a questão do mal não pode ser vista numa abordagem que não tenha em linha de conta o facto trágico da imperfeição do mundo sensível. Herdado de uma tensão (reconhecida até pelo filósofo em IV.81.23-50) interna do platonismo tal qual aparece nos diálogos do mestre ateniense (Fedro e Timeu), Plotino vai reformular este legado platónico, reconduzindo a problemática da matéria ao afrouxamento dispersivo da contemplação infinita. Em suma: no infinito teríamos a coincidência absoluta do olhar com a luz, numa auto-visão que não se subsume debaixo de nenhuma dualidade finita. Esta transparência imediata de si próprio para si mesmo no Uno altera-se profundamente: não por um mal radical imiscuído por ventura na infinitude do Bem, não por uma queda real ou por uma qualquer degradação pérfida do Bem superior, mas sim por uma necessidade livre do infinito poder do Uno. Espontaneamente e sem qualquer planificação calculadora do Uno, distinguem-se numa espécie de visão confusa os que contemplam e os que são contemplados. A contemplação cinde-se da luz e é justamente daqui que nasce a dualidade, o conflito como uma necessária consequência da diversidade contraposta das partes. 0 que importa relevar aqui é justamente que a solução plotiniana reafirmada no presente tratado tem de forma nítida como alvo a denúncia de um gnosticismo típico que tem uma propensão para concluir a maldade geral do mundo material e celeste desde a sua criação. Plotino está certa e interiormente afastado do cosmopolitismo estóico ou até gnóstico: mais do que ressalvar o atrito das partes diagnosticando um mal imanente a toda a emanação do uno, mais do que acentuar o conflito entre os que se instalam no seio e na perspectiva da diferença, o texto plotiniano procura a partir II.9.5 frisar bem que o todo - mesmo composto por opostos - se enquadra numa totalidade conforme a direcção da necessidade e do destino do Bem. Há toda uma simpatia que fundamenta fenomenologicamente o mundo e que resulta directamente de um princípio racional de coerência interna estruturado pela Alma na ordem da totalidade. A Alma é o princípio organizativo do mundo sensivel: enquanto a emanação e a ascensão são aspectos complementares do mesmo processo, é pela mediação da Alma que o mundo sensível deriva do Intelecto e é sustido na duplicidade simultânea deste processo de processão e reintegração. A dor das partes não tem uma origem exclusivamente ontológica; o mal que os heréticos procuram fundar nas onto-mitologias de que são autores não pertence ao domínio da metafísica mas corresponde sim ao espaço ético das liberdades individuais de cada um: interpretando mal a verdade do texto platónico, os heréticos do mundo helénico parecem tomar partido de um desaprovar absurdo da realidade inteligível (II.9.8), da espontaneidade do poder infinito do Uno e das imagens que dele procedem. Aliás, a questão colocada acerca dos heréticos sobre o princípio do cosmos, para Plotino, denuncia desde logo a falta de perspectiva destes sobre a eterna continuidade do todo e da vida que tudo pervaga:

'Perguntar porque é que a Alma fez o cosmos é como perguntar porque é que existe a Alma e porque é que o demiurgo fez [o cosmos]. [...] É uma questão daqueles que assumem um princípio naquilo que existe sempre $[\ldots]$.

II. 9.8.3-4. 
Plotino reconduz o desprezo dos Gnósticos a uma incompreensão da verdadeira doutrina de Platão: apesar de maculado por uma negatividade incontestável, o plano da materialidade, o tempo e em suma, todos os entes enquanto de certa forma 'separados' do Uno, ainda assim só existem através desta unidade (II, 9.9.35 e sggs). Esta teia de dependência do Uno e da sua unidade plasmadora dos entes tem até fortíssimas consequências manifestamente de matiz ético: estando todos os entes ordenados como que numa dança (II,9.7.3540), as acções de cada ente - mesmo que no seu exíguo espaço de acção particular - têm de facto repercussões infinitas não só no seu próprio plano de vida terreno, como de um ponto de vista macrocósmico, afectam, a título de exemplo, as existências quer presentes quer posteriores de todos os seres vivos e as suas próprias. Plotino insistirá também aqui nesta esfera do domínio ético: se o dever de cada Homem é tornar-se Deus ( $\theta \varepsilon \tilde{\omega} \gamma \varepsilon v \varepsilon \dot{\sigma} \sigma \theta \alpha \mathrm{t}, \mathrm{II}, 9.9 .51)$, importa relevar a arrogância daqueles que depois de ouvirem que são 'filhos de Deus ( $\theta \varepsilon$ oṽ $\pi \alpha \tilde{i} \varsigma)$, e de que os outros que admirava não o são, nem os seres que venerava de acordo com a tradição recebida dos seus pais' (II.9.9.57-60), não se dedicam ao exercício da virtude através da liderança do seu intelecto. Aquele que dantes era 'reflectido, modesto e uma pessoa

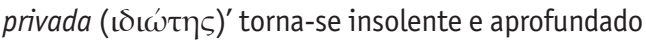
numa vontade individual que não está de acordo com o todo: escapando das verdades da tradição, do respeito pelo ancião, do destino universal do todo, reclama uma negatividade absurda do mundo, da materialidade e até da Alma que o organiza no plano micro e macro cósmico. Sendo com certeza verdade que Plotino não consegue retirar da sua própria concepção uma perspectiva também ela negativa da realidade material do mundo - bastando para isso ver, a título de exemplo, de que Plotino é sem dúvida herdeiro de todo um léxico basilar demarcadamente com uma tendência niilista da realidade do mundo terreno -, não se pode no entanto desprezar o facto de em simultâneo ser de igual forma precisamente através de Plotino que se resolve esta inclinação para o apontar do mal e do seu princípio na escuridão do mundo. A solução de
Plotino caminha a par e passo junto de uma solução platónica: analisar a questão do mal apenas na sua superfície, ou seja, responsabilizando os primeiros princípios ( $\pi \varrho \tilde{\omega} \tau \alpha \alpha i \tau i ́ \alpha)$ não pode deixar de ser um sintoma de uma ignorância da verdade. Plotino, à semelhança de Ireneu remete a sua resposta para uma estratégia que tem como sustentáculo não só um elemento racional, mas também para um componente que diz directamente respeito à tradição de que Plotino é herdeiro. Cada indivíduo deve 'aceitar calmamente a natureza de todas as coisas e dirigir-se para os princípios, cessando de se preocupar com as tragédias de terrores' (II.9.13.3-11) que pululam na alma dos que vivem atormentados por falsidades e superstições (II.9.14). Operando por irradiação e por expansão (V.1.1), o Uno é a causa lógica e evidente da existência de todos os entes - por ser anterior a todas as coisas (V.3.12), nenhum ente pode estar ontologicamente desligado dele: permanecendo em si mesmo, ele esquiva-se a toda a predicação ao mesmo tempo que persiste como objecto de pensamento e de contemplação do que dele provém. Dizer que Deus apenas se ocupa de uma parte dos entes que dele procedem é um erro que obscurece as almas daqueles que veiculam esta mensagem: o mundo é em rigor o mesmo que o Uno - e isto não só porque todos os estão efectivamente numa consonância universal ordenada pela unidade e inseridos numa teia de dependência geral, mas porque radicalmente cada ente é uma unidade múltipla que deriva por efeito do mesmo princípio. Para além de utilizar a tradição como ponto de sustentáculo da sua explanação metafísica, o mais importante em Plotino é justamente a justificação metafísica da sua resposta à questão da existência do mal. 0 mundo tal como é faz parte da mesma ordem que os princípios dos quais em primeiro lugar procedeu: nenhuma parte e muito menos a totalidade se encontra desvinculada da realidade inteligivel que aliás fundamenta estruturalmente o mundo sensível. Proporção, excelência e ordem são qualidades que também este mundo exibe por participar de um inteligível que é o poder infinito que dirige o cosmos. Aos Homens cabe esta exigência de se tornarem melhores e cada vez mais parecidos com o divino: é preciso portanto abandonar uma entanto citar Jonas: 'This is a mixture of ontology and drama, $i$. e., myth. The ontology articulates what time is in counterpart to eternity; the myth relates how time suceded from eternity. In doing so, the myth tells of forwardness and unrest, of an unquiet force, or unwillingness or inability to remain in concentrated wholeness, of a power that is thus at the same time a lack of power, of a desire to be self-subsinstent and separate.'; Cf. 'The Soul in Gnosticism and Plotinus', Le Néoplatonism, Paris, 1971, p. 52. As semelhanças entre os temas Gnósticos e a obra plotiniana é um trabalho fascinante e que está neste momento já muito explorado por exemplo no campo do uso fundamental de uma linguagem tolmática (tolméw); Cf. Joseph Torchia, Plotinus, Tolma, and the Descent of Being, New York, 1993. 
perspectiva presa ao unilateral e dirigirmo-nos para o objectivo da totalidade através do exercício inteligente da virtude. 0 sábio é aquele que de forma reflectida toma em linha de conta não uma parte do todo, mas a totalidade na sua polifonia.

0 que importa ressalvar de forma mais categórica não são de facto os móbeis que animam a intervenção plotiniana no tratado n. ${ }^{0} 9$ da II Enéada: relativamente a isto, Plotino, está sem dúvida muito próximo do bispo de Lyon ao conduzir as linhas de força mais preponderantes do seu texto para um apelo à necessidade lógica da unicidade radical do princípio do cosmos e, por fim, ao remeter esta ideia para uma tradição de autoridade que a legitima. Como referimos no início desta aproximação do trabalho plotiniano, o texto do filósofo egípcio emerge com uma frente 26. Cf. H. Ch. Puech, 'Plotin et les Gnóstiques', in En quête de la Gnose, 1978, I, p. 383 e sggs.

de ataque apenas esboçada: $\mathrm{H}$. Ch. Puech ${ }^{26}$ conclui até que os adversários de Plotino poderiam tratar-se de grupos de cristãos. Enquanto Ireneu obedece a um esquema de exposição e rebatimento das ideias que the são contrárias de uma forma sistemática, Plotino não parece minimamente preocupar-se com esta questão, quer do ponto de vista metodológico, quer do ponto de vista de conteúdos: assim sendo, o texto plotiniano surge muitas vezes com um teor mais de explanação do próprio ponto de vista do autor do que de um confronto directo com os seus adversários. Enquanto Ireneu faz constantemente regressos concretos a passagens da escritura para uma justificação da verdade, Plotino não se parece também preocupar com essa questão: as citações das suas fontes são muitas vezes equívocas e não mostram nitidamente um regresso a um texto em particular. 0s métodos dos dois autores são diferentes, mas e os argumentos entretecidos por ambos são semelhantes? A resposta a uma questão desta só pode ser feita com cautela. Plotino e Ireneu, apesar de imiscuídos num ambiente intelectual semelhante, não procedem rigorosamente do mesmo filão e tendo em conta este aspecto basta só dizer que Plotino está demasiado distante do núcleo mais profundo das teses de Ireneu para fundamentar a ideia de que ambos os autores falam de temas semelhantes: mas não só o fazem de perspectivas diferentes, como precisamente usam categorias em rigor diferentes. Em Plotino não há resquícios da ideia de uma morte e ressurreição de Cristo - este centro histórico-teólogico marcante da consciência mitológica cristã não tem qualquer presença na obra plotiniana seja em que aspecto for: para Plotino este mundo não começou e não será redimido na humilhante e sacrificial presença de um Deus tornado finito. 0 que separa o cristão Ireneu, bispo de Lyon, e o Plotino herdeiro de uma mentalidade e de uma cultura grega é a ideia fundamental de um intelectualismo grego que impregna as Eneádes: e até mesmo numa figura controversa da obra plotiniana como o «misticismo», a sua obra permanece fiel a ideias fundamentais como a da posição do Homem numa esfera de sentido total onde todos os entes sem excepção concorrem para uma identificação com o Uno. Se o Adversus Haereses se ocupa de uma unificação e do estabelecimento da religião cristã contra o que atenta contra ela, se Ireneu acaba por propor uma quadratura de conceitos chave - sem dúvida semelhantes aos do mundo plotiniano - como o Intelecto, a participação, a recapitulação e uma divina Economia, o que mais importa frisar é justamente o facto de que para o bispo de Lyon Deus participa pessoalmente no mundo terreno: o Deus de Ireneu tornou-se homem na história deste mundo para que através dessa incarnação possa advir uma graça transcendente. Para Plotino estamos nitidamente em universos diferentes: o Uno, ou Deus - como algumas vezes Plotino também o cognomina - é acima de tudo a condição de possibilidade de todo o real tornandose finito, determinando-se numa cadeia do Ser e do Tempo que contínua e simultaneamente regressam à eternidade de um indiferenciado positivo. Como todos os gregos, Plotino preocupa-se muito com o problema das relações do Uno e da multiplicidade: desde os pré-socráticos aos estóicos, a sua síntese gravita em torno da ideia da origem, do fundamento último da realidade e da constituição suprema das coisas. Na visão plotiniana do mundo cada alma está na encruzilhada entre a multiplicidade das coisas no mundo e o fim da viagem na unidade radical do todo (VI.9.11.43): o Homem, enquanto ser virado para o quotidiano da praxis está apenas a ligar-se a manifestações exteriores a si próprio e 
desta forma a envolver-se cada vez mais no tempo e na ausência da eternidade. Ao invés, a consciência judaico-cristã da qual Ireneu é um defensor arguto e cuidadoso, é herdeira desde o fundamento de um cuidado mais atento à proximidade e de um elogio da memória histórica que escapa à cultura plotiniana: uma alma virada para o mais alto não pode ter memória porque à partida a visão do filósofo egípcio do mundo rejeita todo o princípio de individuação de qualquer ente. A radicalidade monista de Plotino sublinha a sua estranheza quanto a eventuais paralelismos com o pensamento de Ireneu: tudo é da mesma condição que a natureza divina e eterna do Uno e todas as coisas caminham sem um termo definido para a pureza da unidade. Tudo participa do Uno e é justamente também neste conceito de 'participação' que se movem de igual modo diferenças fundamentais entre os

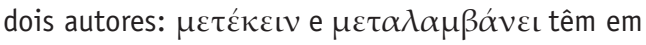
Plotino um significado técnico preciso que remete para a ideia platónica de uma forma que configura de forma radical a identidade dos entes. Para Ireneu a ideia de uma 'participação' está indissociavelmente concatenada com uma Cristologia que gravita em torno da crença de S. Paulo num só deus (Ef. 4:5-6) $(4.32 .1 ; 2.2 .6)$ : para o bispo de Lyon 'participação' significa antes de mais a afinidade entre o que participa e aquele que por amor se dá a participar, ou seja, entre Deus, a sua Imagem, Cristo e em última análise entre Deus e o Homem. Para Plotino tudo está desde o início ao nosso alcance - tratando-se mais este caminho de ascensão da alma um trabalho de reconhecimento do que de outra coisa. A necessidade da contemplação a que Plotino faz constantemente referência nada tem que ver com a fervorosa oração por uma intervenção divina, para uma libertação da graça cujo princípio pode quanto muito descobrir em si mesmo. Para Plotino o primeiro mal é à maneira platónica o resultado de uma obscuridade da ignorância: o afastamento da realidade profunda da unidade última das coisas desembocará por sua vez apenas num fechamento de horizontes do ente em causa. Com Plotino estamos em presença de uma concepção metafísica fundamentalmente ao mesmo tempo que extremamente dinâmica, também ela estática e contínua da realidade. Nenhuma alma tem de em rigor ser metamorfoseada por uma revelação purificadora ou por um advento redentor: para Plotino o único caminho é a supressão de uma perspectiva do exterior, e o de uma reconstituição ascética de um ponto de vista de onde a transcendência seja imanente e simultaneamente de onde a imanência seja absolutamente transcendente.

É certo - como de resto adiantámos no início deste trabalho - que a objectividade do trabalho de exposição de Ireneu sobre os movimentos gnósticos é hoje em dia e cada vez mais, posta em causa: os 'Gnósticos' correspondem a uma categoria construída artificialmente e que engloba demasiados grupos com tendências se não contrapostas pelo menos dissonantes mesmo nas características mais básicas das suas doutrinas. 0 ponto principal deste trabalho é precisamente ressalvar estes três aspectos: por um lado 'os Gnósticos' contra os quais Plotino e Ireneu lutavam são difíceis de discernir com acribia porque as tendências gnósticas eivaram sem dúvida tanto o filósofo egípcio como o bispo de Lyon. Os conceitos e as suas terminologias eram semelhantes, é certo, mas o que os destrinça, mais do que o seu modo de operar conceitos e argumentos, são os objectivos que pretendem. Ireneu de Lyon tem objectivos demasiados diferentes de Plotino para se poderem fazer paralelismos evidentes mas não há dúvida de que falam com uma semântica muito parecida. Para Plotino não advirá qualquer socorro de uma graça transcendente, não há um sinal especial de uma transcendência cujo cuidar se exprime tãosomente pela manutenção e criação de todos os entes: animais, Homem e coisas, bem como mais geralmente, Alma, Intelecto e Tempo são ainda assim também eles entes do mesmo desvelar deste Uno que cuida sem preocupação de si mas por simples, necessária e livre espontaneidade. Enquanto o Deus de Ireneu se ocupa das suas criaturas investindo de forma especial na história da Humanidade, o Deus de Plotino desvela-se sem um sentido de responsabilidade definido no sentido de que não há efectivamente nem pecados a redimir, nem uma teleologia definida a efectivar-se na História - ou em última análise e bem no coração da obra de Ireneu não há uma Fé ${ }^{27}$. Ambos os autores são sem dúvida herdeiros de um complexo paradigma platónico -
27. Jean Daniélou e Henri Marrou caracterizam a obra de Ireneu de Lyon como um 'desenvolvimento do conteúdo da fé'. Cf. Jean Daniélou, Henri Marrou, The Christian Centuries - The First Six Hundred Years, transl. by Vincent Cronin, London, 1978, p.112. 
mas este platonismo só faz sentido quando com ele se quer referir uma comunidade linguística e lexical

28. N. B. Eric Osborn por exemplo reconduz Ireneu a um 'platonismo horizontal' na medida em que o platonismo era sem dúvida uma estrutura da época que cultura impunha ao pensamento. Sublinhe-se o que escreve próprio autor: 'In attributing a Platonic paradigm I am describing the general structure which the culture has imposed on his thought and not a conscious allegiance. We are all members of

a linguistic comunity, which shapes our language'.; Cf. Eric Osborn, Irenaeus of Lyons, Cambridge, 2001 , p. 15, n. ${ }^{0} 36$

29. Cf. J. Fantino, La théologie $d^{\prime}$ Irénée, Paris, 1994, p. 241.

30. Cf. E. R. Dodds, Pagan and Christian in an Age of Anxiety, Cambridge, 1965.

31. N. B.: A expressão é de Dodd e resume bem a nosso ver o que se deduz sumariamente da obra de Plotino. Cf. E. R. Dodds, 'The Parmenides of Plato and the origins of the Neoplatonic One', Classical Quarterly 22, 1928, p. 23.

32. Cf. Eric Osborn, Irenaeus of Lyons, Cambridge, 2001, p. 44

que engendra em profundidade alguns aspectos das grandes temáticas na época desenvolvidas ${ }^{28}$. 0 mesmo se aplica de forma semelhante à questão do gnosticismo: em rigor os dois autores são sem dúvida e de igual modo influenciados pelo próprio ambiente que procuram combater. Se ao génio de Ireneu coube 'a introdução da recapitulação no conceito de economia ${ }^{29}$ e no advento da parousia de Cristo, competiu também ao bispo de Lyon, e em paralelo às muitas formas de progressão temporal gnósticas, admitir a perfeição do conhecimento para os 'últimos dias' (2.4.2). Ao filósofo egípcio o mesmo se aplica: apesar da sua revolta contra os que apenas viam carência e negatividade no plano material, ainda assim o próprio Plotino não se consegue nunca libertar deste matiz herdado do mundo grego. Cabe agora a pergunta: crenças diferentes podem exprimir-se em categorias iguais? Já vimos que algumas das categorias tanto usadas por Ireneu como por Plotino apresentam ao mesmo tempo diferenças e semelhanças marcantes, mas mesmo colocando

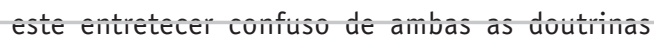
de lado, o que mais fundamental ressalta é a uma consanguinidade dos dois autores com o ambiente de que são filhos. Mais do que filogeneticamente procurar interpenetrações e autênticos jogos de influências mútuas entre o ambiente religioso sincrético em que ambos os autores viviam e a autonomia das suas obras, o que importa relevar é precisamente as suas diferenças fundamentais: partindo do que parecem ser pressupostos semelhantes, organizam o seu discurso com instrumentos semânticos de igual modo parecidos - mas na realidade os dois autores, Ireneu e Plotino, caminham sobre diferentes significados para quanto muito responderem a questões comuns a toda a Humanidade.

\section{Conclusão}

Tendo em conta alguns dos mais significativos trabalhos que se fizeram sobre o tríptico Plotino, Ireneu de Lyon e gnosticismo, esta breve reflexão procurou essencialmente argumentar e estabelecer três aspectos para uma solução da questão: a) Como M. A. Williams, em Rethinking 'Gnosticism' - An argument for dismantling a dubious category aduziu, a categoria 'gnosticismo' é hoje em dia cada vez mais questionável do ponto de vista metodológico: o gnosticismo é um movimento regra geral heteróclito e com poucas linhas de força sólidas, rigorosas e comuns a todas as vertentes. Assim sendo, é possível encontrar, sem grande esforço matizes Gnósticos tanto em Ireneu como em Plotino. Ambos os autores são filhos de uma 'época da ansiedade ${ }^{30}$ e não só as questões que abordam, mas o modo como as colocam e as perspectivas que apontam comungam muitas vezes de alguns princípios partilhados de forma sincrética.

b) Ireneu de Lyon é de facto autor de algumas ideias em tudo semelhantes às que herdou de uma cultura grega inserida numa atmosfera platónica, mas o seu caminho como pensador aponta para uma teologia que se articula com respostas essencialmente características do que veio a fundar o movimento cristão: uma economia divina ordenaria os eventos do mundo terreno, uma recapitulação redentora, um Deus-Intelecto e uma participação dos entites êm Deứs e de Deứs nos entes são os cintilares que gravitam em torno de uma ideia fundamental: a morte e a ressurreição de Cristo, em suma, a Fé.

c) Plotino emerge de um legado mais clássico: organizando uma estrutura metafísica sistemática procura explicar intelectualmente o real erguendo em simultâneo uma filosofia fundamentalmente da contemplação e da introspecção. No seu 'campeonato resoluto da razão $o^{31}$ e em dívida para com a noção de 'sistema' dos estóicos, Plotino está essencialmente preocupado com os problemas característicos da Filosofia Antiga: a conexão Uno-Múltiplo, a questão da realidade última dos entes e da diferença ontológica entre os entes que são e o que é de forma imutável são o eixo fundamental da sua especulação.

Dado o que aduzimos e ao contrário do que a título de exemplo Eric Osborn refere numa das suas obras $^{32}$, concluímos que não se pode em rigor reclamar uma 'quase identidade' entre a especulação plotiniana e o pensamento do bispo de Lyon nem sequer nos termos de uma resposta ao Gnosticismo. É certo que os dois autores partem de uma atmosfera semelhante, esta sim, quase idêntica: mas os 
horizontes de cada um deles são absolutamente diferentes porque procuram resolver questões semelhantes, caminhando sobre pressupostos distintos, reconduzindo-se a tradições na origem absolutamente diferentes e têm como é evidente respostas divergentes.

\section{Bibliografia Primária}

Irenaeus, Against heresis - Adversus Haereses, text, W. Harvey, 2 vols, Cambridge, 1857.

P. Henry and H.-R. Schwyzer (eds.) Plotini opera, Editio minor in 3 vols., Oxford, 1964-1982; Armstrong, A. H., Plotinus, Text with English translation by A. H. Armstrong, 7 vols., Cambridge Mass., 1966-1988.

\section{Bibliografia Secundária}

Armstrong, A. H., "Dualism Platonic, Gnostic, and Christian", in Plotinus amid Gnostics and Christians, 1984.

$\times$ Atkinson, M. J., Plotinus - Ennead V. 1, A commentary and translation., 0xford, 1963.

Balthasar, H. U., Herrlichkeit - Eine theologische Ästhetik, vol II, Eisiedeln, 1962.

Benoit, A., 'Irénée et l'hérésie, les conceptions hérésiologiques de l'évêque de Lyon', Augustinianum, 20, 1980.

Beuzart, Essai sur la théologie d'Irénée, Le Puy, 1908.

Brehier, Emile, The Philosophy of Plotinus, Chicago, 1971.

Daniélou, Jean; Marrou, Henri, The Christian Centuries - The First Six Hundred Years, transl. by Vincent Cronin, London, 1978.

Der Presbyter-Prediger des Irenäus (IV, 27, I -32, I)' in Philotesia. Paul Kleinert zum 70. Geburstag, ed. de A. von Harnack et al., Berlin, 1907.

Dodds, E. R., Pagan and Christian in an Age of Anxiety, Cambridge, 1965.

Dodds, E. R., 'The Parmenides of Plato and the origins of the Neoplatonic One', Classical Quarterly 22, 1928.

Doods, E. R., Le Néoplatonism, Paris, 1971.

Doods, E. R., 'Tradition and Personal Achievement in the Philosophy of Plotinus', in The Ancient Concept of Progress, Oxford, 1973.

Gregory, J., The Neoplatonists, Routledge, London, 1999. Grant, Robert, Irenaeus of Lyons, New York, 1997.

Hegel, Leçons sur l'histoire de la philosophie, trad. Garmiron, Paris, 1975.

Kirk, G. S.; Raven, J. E.; Schofield, M., The Presocratic philosophers, Cambridge, 1983.

Lawson, The Biblical theology of St Irenaeus, London, 1948.

Le Boulluec, Alain, La notion d'hérésie dans la littérature grecque Iie-IIIe siècles, 2 vols, Paris, 1985.

Meijer, P. A., Plotinus on The Good or the One - Enneads VI, 9 - An Analytical Commentary, Amsterdam, 1992.

Meijering, God, being history: studies in patristic philosophy, Oxford and New York, 1975.

Osborn, Eric, Irenaeus of Lyons, Cambridge, 2001.

Puech, H. Ch., 'Plotin et les Gnóstiques', in En quête de la Gnose, 1978.

Rist, J. "Plotinus and Christian Philosophy", in The Cambridge Companion to Plotinus, 1966, p. 386-413.

Runia, D. T., 'Philo of Alexandria and the Greek haeresismodel'; Vigiliae Christianae, 53, 1999.

Sleeman, J. H.,; Pollet, Gilbert, Lexicon Plotinianum, Leiden, 1980.

Stout, Jefferey, The Flight from authority - Religion, morality and the quest for autonomy, Notre Dame, 1981.

Torchia, Joseph, Plotinus, Tolma, and the Descent of Being, New York, 1993.

Vincent, G., 'Le corps de l'hérétique (la critique de la gnose par Irénée)', in Revue d'histoire et de philosophie religieuses, 69, 1989.

Williams, M. A., Rethinking 'Gnosticism'. An Argument for dismantling a dubious category, Princeton, 1996.

Ziegler, Irenäus der Bishof von Lyon, Berlin, 1871. 